\title{
COMPARATIVE FORECAST OF PASSENGER TRANSPORTATION IN LONG HAUL RAILWAY AND LONG-DISTANCE BUS SERVICE
}

\author{
Balaka Ye. I. ${ }^{1}$, Rezunenko M. Ye. ${ }^{1}$, Vdovychenko V. O. ${ }^{2}$ \\ ${ }^{1}$ Ukrainian State University of Railway Transport \\ ${ }^{2}$ Kharkiv National Automobile and Highway University
}

\begin{abstract}
Problem. The article presents methodological approaches to determining the volume of passenger service in long-distance railway connections and intercity bus services in Ukraine, which are expected in the coming years. Goal. The purpose of the study is to increase the reliability of the information base for making informed management decisions on the further development of the transport passenger complex. Methodology. In the process of research there was used a set of methods of expert assessment and logical analysis of possible factors influencing; economic and mathematical modeling; formalized extrapolation methods to determine the predictive parameters of influencing factors. Results. The forecast values of the number of transported passengers and the values of passenger turnover in long-distance railway and intercity bus connections in the short-term period are obtained. Originality. To estimate the forecast values of passenger traffic there was used the combination of methods of correlation-regression analysis and forecasting the magnitude of factors by the method of variable average. Practical value. The study of the patterns of passenger traffic dynamics revealed that in the next two years no significant changes are expected in the volume of work of both kinds of transport. However, in long-distance railway transport it is possible to increase passenger traffic by $1.6 \%$ (0.74 million passengers) and, accordingly, the annual passenger turnover will increase by $2.2 \%$. In the intercity bus service, a slight decrease in the volume of passenger traffic by $0.8 \%$ (0.93 million passengers) is possible, and the rate of decrease in annual passenger turnover will be $0.5 \%$. In the conditions of constant reduction of the population of Ukraine the most effective mechanism of ensuring further sustainable development of both types of passenger transportation is constant adjustment of tariff policy on the principles of flexibility and bonus tariff formation under condition of continuous improvement of services quality.
\end{abstract}

Key words: forecasting, passenger traffic, railway, bus service, correlation and regression analysis.

\section{Introduction}

Transport service has always occupied a special place in the public life. The rapid growth of the migration activity of the population, which is being observed at the present stage of the scientific and technological revolution, is naturally determined. This pattern is stipulated by the causal relationship between supply and demand in the system of social and economic relations, which is constantly changing.

Fierce competition in the market of goods and services gives impetus to the technical and technological development of the productive forces of society, which, in turn, causes a chain reaction of innovative transformations in all sectors of the economy. The result is an increase in production and a variety of end products. There are new features of the economic system, which, are inevitably associated, on the one hand, with the exacerbation of the movement of labor, and on the other hand - with the need for appropriate growth in sales of goods and services, dictated by laws of goods-money relation- ships in market conditions. This second component of socio-economic development causes an increase of people's income, raising their living and social standards and, as a consequence, levelling up the demand for transport services and the requirements for their quality. There is no doubt that these patterns are causal and are a form of manifestation of the general laws of dialectics, namely: the transition from quantitative to qualitative changes, the combination and struggle of opposites, the negation of the negation, and therefore they are fully inherent in the processes of development of passenger segment in the national transport industry. Understanding of these laws allows to optimize management decisions, predict their results and, thus, to avoid undesirable consequences or soften their negative impact on the process of transport activity. In this sense, forecasting the volume of passenger transportation is the initial stage and a necessary condition for scientific prediction of this process. 
Ukraine, with an area of 603.55 thousand square kilometers, ranks forty-fourth among all countries in the world and second among European countries according to this indicator. In terms of population, as of 2020, our country ranks thirty-fourth in the world ranking and seventh in the European. The transport network of Ukraine covers almost 20 thousand $\mathrm{km}$ of railways and about 163 thousand $\mathrm{km}$ of roads, of which 159.5 thousand $\mathrm{km}$ are paved [1].

Analysis of the condition status and development of the network of railways and highways in Ukraine and in the developed countries of the West makes it possible to draw the conclusions that:

- Ukraine has an extensive network of railways, occupying a worthy place among the economically developed countries of the world. However, the wear of passenger rolling stock exceeds $90 \%$, which creates a threatening situation for the further development of the industry in general and for transport services in particular;

- the network of national highways in its length and quality is much inferior to Western countries (the total length of highways is only $200 \mathrm{~km}$ ), which significantly hinders the development of road passenger transport.

\section{Analysis of publications}

The conceptual principle of the passenger transport service system is integration, which makes it impossible to obtain the maximum effect without a multifaceted approach to solving the problems of the industry, i.e. requires the simultaneous development of all its basic and infrastructural elements: renewal of rolling stock, development of roads, improving the quality and variety of services, etc. Problems of improving the efficiency of passenger transport services and increasing the efficiency of the transport system elements is of great scientific and practical interest. Possible conceptual approaches and specific proposals for solving these issues in various aspects of the passenger complex are highlighted in numerous studies. Among them, the well-founded proposals to improve the financial and economic condition of transport systems, the works on the analysis of existing problems of the industry, assessment of the prospects for its further development by using various methods of scientific prediction are especially noteworthy.

Thus, in [2] the possible options for reforming the tariff policy on railway transport are analyzed on the basis of assessing the parameters of competitiveness formation. In [3] the author presents a comprehensive analysis of revenues from passenger transportation under the condition of improving the quality of services.

An important problem, whose solution significantly contributes to the effective management and development of the transport system, is the forecasting of passenger transportation. In [4-6] methods of forecasting air transportation are presented, a methodical approach for determining forecast estimates of volumes of passenger railway transportation in long haul communication is offered in [7-10], the research in [11] is devoted to forecasting railway suburban passenger flows, [12] offers effectively implemented forecasting within the strategic planning of the transport system, in [13] the models of demand in long haul road transport are developed, in [14] the forecast models of passenger transportation are used for the formation of professional competencies of specialists in the field of road transport.

The task of forecasting the volume of transport demand is non-trivial and complex, which necessitates the use of appropriate scientifically sound tools. Analyzing works [4-14], it is possible to classify the existing approaches to forecasting the volume of passenger transportation in terms of the applied mathematical apparatus according to the following categories:

- based on time series [5, 9, 12];

- based on correlation-regression analysis $[4,7,8,14]$;

- predictive models based on the elements of artificial intelligence [10, 11];

- analytical models $[6,13]$.

Forecasting the volume of traffic based on the analysis of time series enables to objectively assess the existing trend towards its change and to provide high accuracy in case of stability in the formation of the trend. However, some years of the recent period showed is a significant abrupt decrease in passenger transportation in Ukraine, which is due to the existing territorial and political circumstances. Therefore, the formal application of only extrapolation methods based on the smoothing of time series can give a significant error. However, this method allows obtaining adequate results if it is used in combination with the method of correlation-regression analysis [7].

Correlation-regression analysis can significantly improve the reliability of the forecast by establishing the characteristic impact of a set of factors that determine the level of population demand for transport services. The main prob- 
lematic aspects of the application of correlationregression analysis for forecasting the volume of traffic are that it needs a sufficient amount of statistical sampling to be used and an expert identification of the factors of influence.

The main direction for realizing the principles of application of artificial intelligence for forecasting the volume of traffic is the use of neural networks. This approach is promising today, its results are extremely accurate and it makes possible to establish a relationship for a large number of impact factors. However, its application for forecasting indicators at the macro level is complicated by the need to conduct a significant number of experiments within the procedure of learning the neural network and obtaining the number of input parameters in a wide range of variation. As a result, it devalues their practical usage in forecasting the total volume of passenger transportation.

The main disadvantage of analytical forecasting models is the complexity and low versatility, which is manifested in the demand to calibrate them for specific subjects.

Based on the presented analysis of literature sources and taking into account the social significance of transport services for the population, there is an objective need to predict the volume of passenger transportation in long haul services based on combined statistical models.

\section{Purpose and objective}

The purpose of the study is to forecast the volume of passenger transportation in long haul (railway) and long-distance (road transport) service in the short term, which will provide a higher level of reliability of information sources to make informed management decisions concerning further development of the transport industry.

Achieving this goal is dictated by the solution of such problems:

- identification of the main socio-economic factors influencing the activity of the passenger complex;

- determination of the degree of impact of these factors on the volumes of the specified passenger transportation and construction of the correlation-regression model which makes possible to reveal regularity and estimate quantitative values of parameters of transport service for the population;

- forecast estimates of the value of factors that determine the volume of passenger transportation;
- forecast of the volume of passenger transportation in long haul railway and long-distance road transport services in the short-term period of prediction.

\section{Statistical estimation of passenger transportation volumes}

Identifying the ways to further develop the passenger sector in the domestic transport service system is one of the most important ways to improve the functioning of the infrastructure component of Ukraine's economy. The validity and timeliness of working out the strategic programs for the development of this sphere of society determines future allocation and distribution of material and financial resources in elaboration of short-term and medium-term plans for the passenger complex, optimization of volumes and structures of both state and private investment in this segment of the transport sector.

There is no doubt that the appropriate forecast estimates of its development are the basis for studies of the trends and future state of any economic system in market conditions. A necessary condition for strategic programming is the development of medium- and long-term forecasts with a prediction period of five, ten years or more. The reliability of such predictions is ensured above all by the use of intuitive (expert) methods of extrapolation, as the formalized methods do not enable to obtain reliable results in the long run. In its turn, medium- and longterm forecasts are based on the short-term forecast estimates, whose high level of reliability is ensured by the use of formalized methods. In addition, short-term forecasts are the basis for drawing up indicative development plans for both the transport industry in general and the passenger sector in particular. Thus, the desire to increase reliability permanently actualizes the process of improving the forecasting methodology.

The main types of transport used by the population for the implementation of long haul and long-distance communication are rail, road and air transport. The number of transported passengers according to the State Statistics Service of Ukraine $[1,15,18]$ in long haul (railway transport), long-distance (road transport) communication, as well as by air transport is presented in the form of graphs in Fig. 1.

High maneuverability, accessibility, wide scope of application by types of service, rationality of transportations on the average distance up to $300 \mathrm{~km}$ and smaller compared to the railway specific investments in road construction 
provided road transport with a leading position in this segment of the transport market. High handling and carrying capacity of railway lines, the possibility of comfortable conditions for passenger transportation have stipulated the leading role of the railway in the transport service of the population with an average travel distance of over $500 \mathrm{~km}$.

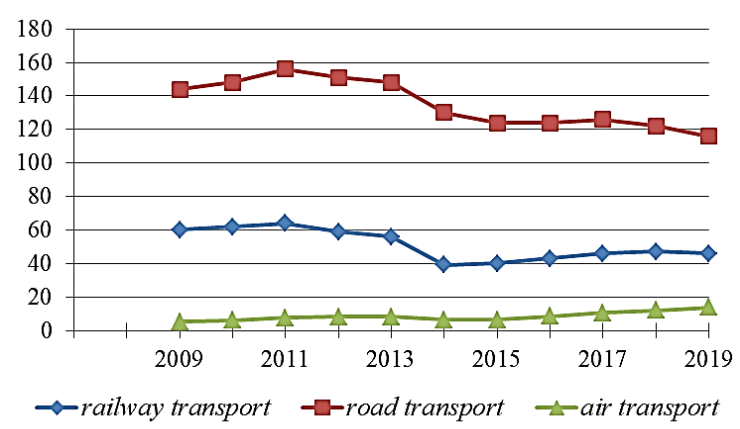

Fig. 1. Dynamics of changes in the volume of passenger transportation for the period of 2009-2019 (million passengers)

Fig. 2 presents the shares of the volume of passenger transportation by various modes of transport for the period of 2009-2019.

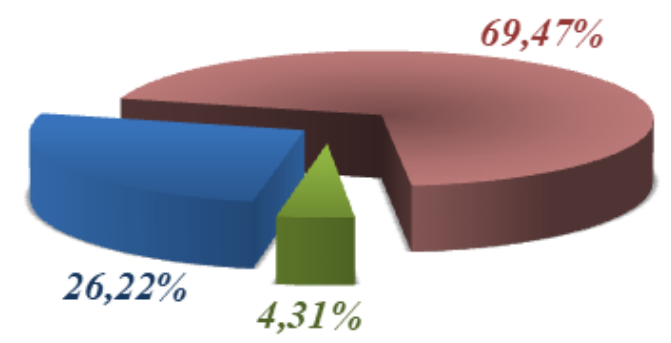

\section{- railway transport 1 road transport \\ air transport}

Fig. 2. Distribution of the kinds of transport in total transportation of passengers for the period of 2009-2019

As it can be seen from Fig. 2, almost $96 \%$ of all long haul passenger transportation is performed by the automobile and railway industries. Given their dominance in this area of transport, it makes sense, in our opinion, to focus on statistical analysis of road and rail transport. It is noteworthy that over the past five years, the aviation industry has doubled passenger transportation from 6.3 million in 2015 to 13.7 million in 2019 , with an average distance of mostly international routes of more than $2,000 \mathrm{~km}$, which provided it with a high level of competitiveness in this segment of the transport market. It helps to remember that in conditions of low prices for oil products a few decades ago air transport successfully competed with land transport not only in interregional, but also in intraregional passenger transportation at distances within $100 \mathrm{~km}$. Given the reduction in world oil prices by 2.5 times over the past six years, we can expect its gradual return to this area of activity.

To forecast transport service for the population in long haul and long-distance communications it is expedient to use the method of correlation-regression analysis and the method of extrapolation, which is shown in [7]. However, as mentioned above, the most important condition for the use of correlation-regression analysis is a reasonable choice of factors that affect the volume of work of the passenger complex.

In this study in order to determine such factors in addition to formal approaches to assessment of their significance by the criteria of statistical analysis $[16,17]$ much attention was paid to the logical analysis of causal relationships between the factors that most significantly affect the volume of traffic, i.e.: the total population of the country, the number of active population aged 15 to 70 , the ratio of these indicators, the dynamics of income and tariffs for transportation, the average number of trips per person per year, the average distance, etc.

Logical and statistical analyses of their significance allowed us to conclude that when building an economic-mathematical model adequately describing the process of passenger transportation in long haul rail and long-distance bus services, it is advisable to take into account four factors that statistically significantly affect the workload of passenger complex, namely: total population $\left(N_{p}\right)$, income (average annual wage $\left.-S_{p}\right)$, transport tariffs $\left(R_{t}\right)$, average distance of transportation $\left(L_{t}\right)$.

The forecast of passenger transportation volumes in long haul (long-distance) communications by land transport was carried out in the following order: firstly, by means of a method of correlation-regression analysis the quantitative estimation of closeness and directionality of interrelation between the volume of transportation and the selected socio-economic factors was determined; secondly, based on regression analysis a mathematical model was built, which describes the dependence of traffic volumes on the influence of selected factors; thirdly, the predicted values of these factors for the correspond- 
ing period of prediction (two years) were determined; fourthly, a forecast estimate of the volume of passenger transportation by rail and bus in the specified type of communications was made by using a correlation-regression model and the forecast values of the selected four factors. This approach, in our opinion, provides the necessary and sufficient conditions for obtaining a reliable forecast of passenger transportation in the short term.

For correlation-regression analysis and construction of a mathematical model, statistical data of the operation of railway and automobile passenger complexes for the period of eleven years (2009-2019) were used [1, 18]. This helped to obtain the equations of multifactor regressions, which adequately describe the dependence of passenger transportation on the selected factors of impact. For long haul railway service, the model for determining the annual volume of transportation has the following form:

$$
\begin{gathered}
Q_{n 3}=-84.142+4.977 N_{p}+0.00084 S_{p}+ \\
+4.32 R_{t 3}-0.17 L_{t 3}
\end{gathered},
$$

where $Q_{n 3}$ - is the number of passengers carried by railway per year, million passengers;

$N_{p}$ - is the total population of Ukraine, million people;

$S_{p}$ - is the average salary of the population per year, $\mathrm{UAH}$;

$R_{t 3}$ - is the income rate (tariff) for 10 passenger-km by railway, $\mathrm{UAH}$;

$L_{t 3}-$ is the average distance traveled by a passenger on railway routes, $\mathrm{km}$.

For long-distance bus service, the model for determining the annual volume of traffic has the following form:

$$
\begin{gathered}
Q_{n a}=-8.253+2.817 N_{p}+0.00009 S_{p}+ \\
+0.707 R_{t a}+0.081 L_{t a}
\end{gathered},
$$

where $Q_{n a}$-is the number of passengers carried by road per year, million passengers;

$R_{t a}$ - is the average tariff for 10 passenger-km on motor transport in long-distance communication, UAH;

$L_{t a}$ - is the average distance traveled by a passenger on long-distance bus routes, $\mathrm{km}$.

The correspondence of the obtained models and the significance of the regression parameters are confirmed by the Fisher and Student criteria.
The coefficient of $R^{2}$ determination, the average error of approximation and the standard error for each of the models are given in Table 1.

The forecast values of the factors influencing the volume of passenger transportation by both kinds of transport were obtained using the method of extrapolation based on the variable average for the recent five years (2015-2019) [19].

Table 1 - Indicators of statistical significance of regression coefficients

\begin{tabular}{|c|c|c|c|}
\hline $\begin{array}{c}\text { Type of } \\
\text { transport }\end{array}$ & $\begin{array}{c}\text { Coefficient } \\
\text { of determi- } \\
\text { nation }\end{array}$ & $\begin{array}{c}\text { Standard } \\
\text { error (mil- } \\
\text { lion pass.) }\end{array}$ & $\begin{array}{c}\text { The average } \\
\text { error of } \\
\text { approxima- } \\
\text { tion }\end{array}$ \\
\hline Railway & 0.9697 & 1.97 & $0.68 \%$ \\
\hline $\begin{array}{c}\text { Road } \\
\text { transport }\end{array}$ & 0.941 & 4.41 & $0.52 \%$ \\
\hline
\end{tabular}

The difference in methodological approaches to the duration of time periods when building the correlation-regression model (eleven years) and the predicted values of the factors (five years) is explained by the following conditions:

- in the forecast calculation of the factors their dynamics was taken into account only on the controlled territory of Ukraine (without ORDLO and AR Crimea), it provides a reliable statistical assessment of passenger transportation in the current conditions of the transport complex of Ukraine;

- levels of impact of selected factors, determined by correlation coefficients, are relatively constant and do not depend on the changes in socio-political conditions, but in building the model the use of statistics for eleven years allows to obtain a more reasonable forecast estimate of passenger transportation.

According to statistics, the trend of changes in the total number of population and the average income per year are described by the functions of the following type:

$$
\begin{gathered}
N_{p}=39.78-0.16 t \\
S_{p}=46714 t^{0.58},
\end{gathered}
$$

where $t-$ is the ordinal number of the year in the time series.

The coefficients of $R^{2}$ determination for regularities $(3,4)$ are equal to 0.985 and 0.965 , and the standard error $(S)$ is, respectively, 0.04 and 0.33 . The trends in changes of passenger tariffs $\left(R_{t 3}, R_{t a}\right)$ per 10 passenger-km are given in Table 2. 
Table 2 - Trends of passenger tariffs changes

\begin{tabular}{|c|c|c|}
\hline $\begin{array}{c}\text { Type of } \\
\text { transport }\end{array}$ & Trends of change & $\begin{array}{c}\text { Indicators of } \\
\text { statistical } \\
\text { significance }\end{array}$ \\
\hline Railway & $R_{t 3}=2.038+0.244 t$ & $\begin{array}{c}R^{2}=0.93 \\
s=0.12\end{array}$ \\
\hline $\begin{array}{c}\text { Road } \\
\text { transport }\end{array}$ & $R_{t a}=4.73+0.82 t$ & $\begin{array}{c}R^{2}=0.9 \\
s=0.1\end{array}$ \\
\hline
\end{tabular}

Trends of changes in the average distance of passengers' transportation for the considered kinds of transport $\left(L_{t 3}, L_{t a}\right)$ are given in Table 3.

Table 3 - Trends of changes in the average distance of passenger transportation

\begin{tabular}{|c|c|c|}
\hline $\begin{array}{c}\text { Type of } \\
\text { transport }\end{array}$ & $\begin{array}{c}\text { Trends of } \\
\text { change }\end{array}$ & $\begin{array}{c}\text { Indicators of sta- } \\
\text { tistical signifi- } \\
\text { cance }\end{array}$ \\
\hline Railway & $L_{t 3}=486.81+3.4 t$ & $\begin{array}{c}R^{2}=0.951 \\
s=0.143\end{array}$ \\
\hline $\begin{array}{c}\text { Road } \\
\text { transport }\end{array}$ & $R_{t a}=278.0+0.8 t$ & $\begin{array}{c}R^{2}=0.889 \\
s=0.516\end{array}$ \\
\hline
\end{tabular}

\section{Forecasting traffic volumes in the short term}

Forecasting the volume of long haul and long-distance passenger transportation occupies a special place among the many problems of organizing the work of rail and road transport. Based on the established trends of change in the factors of impact on the volume of passenger transportation, their forecast values for each type of transport for the short-term prediction period (two years - 2020 and 2021) are determined. The results of the calculations are presented in Tables 4 and 5.

Table 4 - Estimated values of the model factors for long haul railway passenger transportation

\begin{tabular}{|l|c|l|}
\hline \multicolumn{1}{|c|}{ Indicator } & 2020 & 2021 \\
\hline Population, million people & 38.82 & 38.66 \\
\hline Income per year, UAH & 132061 & 144412 \\
\hline $\begin{array}{l}\text { Tariff for 10 passenger-km, } \\
\text { UAH }\end{array}$ & 3.50 & 3.75 \\
\hline $\begin{array}{l}\text { The average distance trav- } \\
\text { eled, km. }\end{array}$ & 507.2 & 510.6 \\
\hline
\end{tabular}

Table 5 - Predicted values of the model factors for long-distance bus transportation of passengers

\begin{tabular}{|l|c|c|}
\hline \multicolumn{1}{|c|}{ Indicator } & 2020 & 2021 \\
\hline Population, million people & 38.82 & 38.66 \\
\hline Income per year, UAH & 132061 & 144412 \\
\hline $\begin{array}{l}\text { Tariff for 10 passenger-km, } \\
\text { UAH }\end{array}$ & 9.65 & 10.47 \\
\hline Average distance, km & 282.8 & 283.6 \\
\hline
\end{tabular}

Table 6 presents the forecast values of the possible volume of passenger transportation in the next two years.

Table 6 - Short-term forecast of the possible volume of passenger transportation

\begin{tabular}{|l|c|c|}
\hline \multicolumn{1}{|c|}{$\begin{array}{c}\text { Type of } \\
\text { transportation }\end{array}$} & 2020 & 2021 \\
\cline { 2 - 3 } $\begin{array}{l}\text { Long haul railway } \\
\text { transportation, mil- } \\
\text { lion pass. }\end{array}$ & 47.40 & 48.14 \\
\hline $\begin{array}{l}\text { Long-distance bus } \\
\text { transportation, mil- } \\
\text { lion pass. }\end{array}$ & 118.86 & 117.93 \\
\hline
\end{tabular}

Based on the use of correlation-regression models $(1,2)$ and forecast values of the above factors (tables 4,5 ), the forecast estimates of passenger transportation by both kinds of transport for the period 2020-2021 were determined.

It should be noted that the proposed model does not take into account the situation of a sharp decrease in internal migration of the population due to restrictions on the use of transport during the Covid-19 pandemic. Based on this, it must be observed that the obtained statistical models are instrumental in determining the overall potential demand of the population for long haul railway and long-distance bus services in terms of overcoming the pandemic situation.

Based on the obtained data and taking into account the forecast average distances of passenger transportation, the forecast volumes of passenger transportation for both kinds of transport were determined. When transported by railway in 2020, passenger turnover was expected in the amount of 24041.28 million passenger-km, in 2021 - 24580.28 million passenger-km; in the bus service in 2020 33613.61 million passenger-km, in 2021 33444.95 million passenger-km. Fig. 3, 4 present forecast of passenger transportation and passenger turnover in the short term.

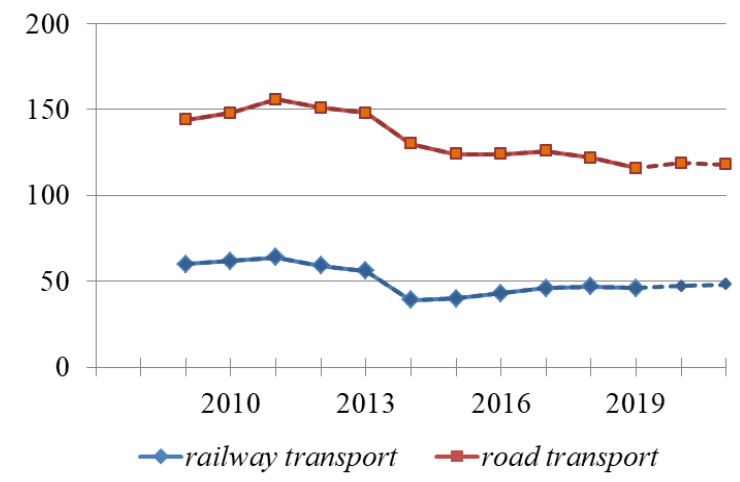

Fig. 3. Dynamics of changes in passenger transportation, taking into account the forecast for 2020-2021 (million passengers) 
The dynamics of passenger transportation in recent years and their short-term forecasts reflect a more optimistic scenario for development of the society in the conditions that preceded the pandemic period.

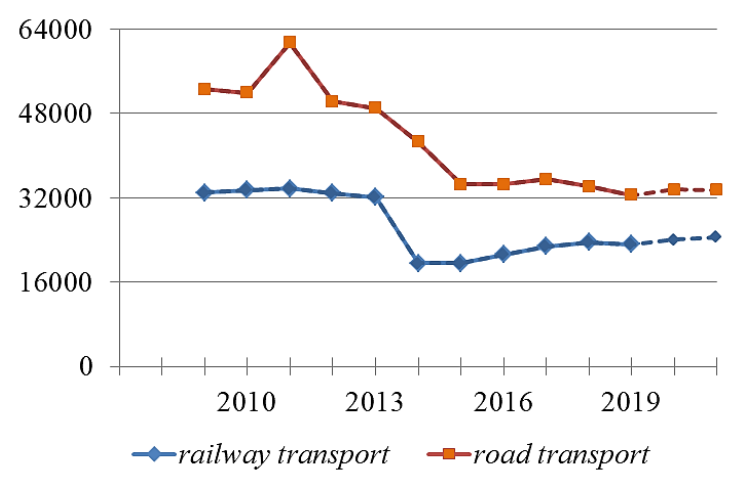

Fig. 4. Dynamics of passenger turnover change taking into account the forecast for 2020 2021 (million pass-km)

\section{Analysis of prospects for the development of railway and road transport}

The main task which solves forecasting in transport is assessing the parameters of demand formation from the standpoint of presenting it as the source information to work out a strategy for the long-term development of enterprises and the industry as a whole. Thanks to the obtained forecast values of the parameters of demand for passenger transportation in long haul and longdistance services, it is possible to get not only a fairly objective idea of possible trends of transport development in the future, but also to form scientifically sound recommendations for strategic management decisions.

Analyzing the current trend for 2009-2019 and obtaining forecast values of passenger transportation for 2020-2021, it is possible to draw the following conclusions:

- $\quad$ in the period from 2009 to 2014 there were similar trends of the gradual decline in transportation by both kinds of transport;

- in 2014 there was a rapid decline in transportation, which is explained not only by the impossibility of transport links with the settlements on the temporarily uncontrolled territory of Ukraine and, as a consequence, led to the lack of statistical accounting of transport in these regions, but also by deteriorating socioeconomic status of the country;

- starting from 2015, there has been a positive trend in increasing the volume of long haul passenger transportation, due to higher incomes and lower rates of tariffs growth compared to road transport;
- in 2020-2021 a small increase of $1.6 \%$ in the volume of passenger transportation by railway and a very small (by $0.8 \%$ ) reduction in demand for long-distance bus transportation is expected; these estimates are in line with the conditions for overcoming the pandemic crisis and do not take into account the quarantine restrictions that were introduced during the year to overcome it;

- taking into account the established tendencies of change in the population demand for transport service it is expedient to focus on solution of the following strategic problems of the further development of railway and road transport:

- rapid and full-scale renewal of the rolling stock, formation of strategic potential of railway transport resources for the total coverage of the territory of Ukraine by high-speed passenger services;

- introduction of unified regulations and conditions of passenger transportation, creation of a unified monitoring and ticketing systems for different kinds of transport;

- development and implementation of a single system of evaluating the quality of transport services;

- organization of direct mixed passenger transportation by different kinds of transport, coordination of schedules and expansion of the practice of cooperative use of existing and construction of new combined stations;

- systematic cooperative inspection of passenger flows and determination of the volumes of passenger trains traffic and intensity of road transport traffic on their basis.

In addition, one of the rules for Japanese business circles to coexist in a competitive environment is worth sharing. It is called "Strategic Alliances" and says "If you are unable to defeat them, unite with them" [20]. In this sense, it is advisable to consider in future the possibility of creating transport associations in the field of passenger transportation on the basis of a consortium or a joint stock company that would carry passengers on a door-to-door basis using different kinds of transport. That is, we are talking about the transition from a purely technological form of building transport enterprises to a mixed one, which will provide a full and complete cycle of quality transport services, reduce marketing and competition costs and increase the investment potential of such transport entities.

\section{Conclusion}

The proposed methodological approach makes it possible to determine the forecast of 
the volume of passenger railway and bus transportation in long haul and long-distance communications with a high degree of reliability. Qualitative short-term forecast values of passenger transportation volumes have been obtained, which take into account the existing socioeconomic conditions. The given forecast estimations are the basis for substantiating the developed plans of the land passenger service system operation in the specified years, namely, determining the need for vehicles, fuel-energy, material, labor, financial resources. They are instrumental in appraising the possible economic indicators in this type of transport activity, its profitability and competitiveness, in making managerial decisions of a strategic nature.

\section{References}

1. Державна служба статистики України. URL: http://www.ukrstat.gov.ua (дата звернення: 10.06.2020).

2. Балака Е. И., Чередниченко А. Ю. Концепция формирования тарифной политики как фактор конкурентоспособности железнодорожного транспорта. Вісник Харківського наиіонального університету ім. В. Н. Каразіна. Сер. Економіка. 2001. №512. С. 57-59.

3. Аксёнов И. М. Предпринимательство и бизнес в сфере пассажирских перевозок. Залізничний транспорт України. 2000. №1. С.28-31.

4. Омельяненко С. Л. Методи прогнозування авіаційних перевезень в Україні. Залізничний транспорт Украӥни. 2004. №3. С. 69-70.

5. Kim S. Forecasting short-term air passenger demand using big data from search engine queries. Automation in Construction. 2016. № 70. P. $98-$ 108.

6. Fildes R., Wei Y., Ismail S. Evaluating the forecasting performance of econometric models of air passenger traffic flows using multiple error measures. International Journal of Forecasting. 2011. №27(3). P. 902-922.

7. Прогнозування обсягів пасажирських перевезень в дальньому залізничному сполученні на основі багатофакторного аналізу / Балака Є. I., Резуненко М. Є., Резуненко С. О., Попов М. А. Збірник наукових пращь Українського державного університету залізничного транспорту. 2019. №185. C. 6-14.

8. A hybrid model for forecasting the volume of passenger flows on Serbian railways / Glišović N., Milenković M., Bojović N., Švadlenka L., Avramović Z. Operational Research. 2016. №16(2), P. 271-285.

9. SARIMA modelling approach for railway passenger flow forecasting / Milenković M., S sadlenka L., Melichar V., Bojović N., Avramović Z. Transport. 2018. №33(5). P. 1113-1120.

10. Tsai T. H., Lee C. K., Wei C. H. Neural network based temporal feature models for short-term railway passenger demand forecasting. Expert Systems with Applications. 2009. 36(2), P. 37283736.

11. Бутько Т. В., Константінов Д. В., Деревянко Т. О. Моделювання системи оперативного прогнозування пасажиропотоків у приміському сполученні на основі використання інтелектуальних технологій. Eastern-European Journal of Enterprise Technologies. 2009. № 1/3 (37). C. 43-47.

12. Forecast of passenger and freight traffic volume based on elasticity coefficient method and Grey model / Wang Y., Chen X., Han Y., Guo S. Procedia-Social and Behavioral Sciences. 2013. №96. P. 136-147.

13. Горбачов П. Ф., Шевчук О. Ю. Оцінка параметрів попиту на перевезення пасажирів між містами України. Вестник Харьковского национального автомобильно-дорожного универcumema. 2016. №72. C. 75-82.

14. Vdovychenko V., Kopytkov D. Statistical evaluation of test results in the transportation managers'training. Проблеми $і$ иляхи забезпечення якості вищої освіти щзодо підготовки фахівиів у сучасних умовах: матеріали інтернет-конференції. Харків, 2016. С. 31-34.

15. Транспорт і зв'язок України 2018: статистичний збірник. Державна служба статистики України. 2019. 154 с.

16. Афифи А., Эйзен С. Статистический анализ. Подход с использованием ЭВМ. Москва, 1982. $488 \mathrm{c}$.

17. Львовский Е. Н. Статистические методы построения эмпирических формул: учеб. пособие для вузов. Москва, 1988. 239 с.

18. Довідник основних показників роботи регіональних філій АТ «Українська залізниця» (2004-2019 роки). Київ, 2020. 39 с.

19. Писаревський І. М., Балака Є. І., Балака Л. О. Основи економічного і соціального прогнозування: навч. посіб. Харків, 2001. 78 с.

20. Tatsuno S. The technopolis strategy. NY: Brady Book-Prentice Hall Press, 1986. 344 p.

\section{References}

1. Derzhavna sluzhba statistiki Ukraine [State Statistics Service of Ukraine]. URL: http://www.ukrstat.gov.ua (date of application: 10.06.2020). [in Ukrainian].

2. Balaka E., Cherednichenko A. (2001). Kontseptsiya formirovaniya tarifnoy politiki kak faktor konkurentosposobnosti zheleznodorozhnogo transporta [The concept of the formation of tariff policy as a factor in the competitiveness of rail transport]. Visnik Harkivskogo natssonalnogo unsversitetu im. Karazina. Seriya: ekonomika. 512. 57-59. [in Russian].

3. Aksyonov I. (2000). Predprinimatelstvo i biznes v sfere passazhirskih perevozok [Entrepreneurship and business in the field of passenger transporta- 
tion]. Zaliznichniy transport of Ukraine. 1. 28-31. [in Russian].

4. Omelyanenko S. (2004). Metodi prognozuvannya aviatsiynih perevezen $\mathrm{v}$ Ukrayini [Methods of air traffic forecasting in Ukraine]. Zaliznichniy transport of Ukraine. 3. 69-70. [in Ukrainian].

5. Kim S. (2016). Forecasting short-term air passenger demand using big data from search engine queries. Automation in Construction. 70. 98-108.

6. Fildes R., Wei Y., Ismail S. Evaluating the forecasting performance of econometric models of air passenger traffic flows using multiple error measures. International Journal of Forecasting. 2011. №27(3). P. 902-922.

7. Prognozuvannya obsyagiv pasazhirskih perevezen $\mathrm{v}$ dalnomu zaliznichnomu spoluchenni na osnovi bagatofaktornogo analizu [Forecasting the volume of passenger traffic in long-distance rail services based on multifactor analysis] / Balaka E. I., Rezunenko M. E., Rezunenko S. O., Popov M. A. (2019). Zbirnik naukovih prats ukrayinskogo derzhavnogo universitetu zaliznichnogo transportu. 185. 6-14. [in Ukrainian].

8. A hybrid model for forecasting the volume of passenger flows on Serbian railways / Glišović N., Milenković M., Bojović N., Švadlenka L., Avramović Z. Operational Research. 2016. №16(2), P. 271-285.

9. SARIMA modelling approach for railway passenger flow forecasting / Milenković M., Švadlenka L., Melichar V., Bojović N., Avramović Z. Transport. 2018. №33(5). P. 1113-1120.

10. Tsai T. H., Lee C. K., Wei C. H. Neural network based temporal feature models for short-term railway passenger demand forecasting. Expert Systems with Applications. 2009. 36(2), P. 37283736.

11. Butko T., KonstantInov D., Derevyanko T. (2009). Modelyuvannya sistemi operativnogo prognozuvannya pasazhiropotokIv v primIskomu spoluchennI na osnovI vikoristannya Intelektualnih tehnologIy [Modeling of the system of operative forecasting of passenger flows in suburban communication on the basis of use of intelligent technologies]. Eastern-European Journal of Enterprise Technologies. 1/3(37). 4347. [in Ukrainian].

12. Forecast of passenger and freight traffic volume based on elasticity coefficient method and Grey model / Wang Y., Chen X., Han Y., Guo S. Procedia-Social and Behavioral Sciences. 2013. №96. P. 136-147.

13. Gorbachov P., Shevchuk O. (2016). Otsinka parametriv popitu na perevezennya pasazhiriv mizh mistami Ukrayini [Estimation of parameters of demand for transportation of passenger cars between the cities of Ukraine]. Vestnik Harkovskogo natsionalnogo avtomobilnodorozhnogo universiteta. 72. 75-82. [in Ukrainian].

14. Vdovychenko V., Kopytkov D. (2016). Statistical evaluation of test results in the transportation managers'training. Problemi $i$ shlyahi zabezpechennya yakosti vischoyi osviti schodo pidgotovki fahivtsiv $u$ suchasnih umovah: materiali internet-konferentsiyi. (Harkiv, 11 November 2016). 31-34.

15. Transport i zv'yazok Ukrayini 2018: statistichniy zbirnik [Transport and Communications of Ukraine 2018: a statistical collection]. Derzhavna sluzhba statistiki Ukrayini. 154. [in Ukrainian].

16. Afifi A., Eyzen S. (1982). Statisticheskiy analiz. Podhod s ispolzovaniem EVM [Statistical analysis. The computer-based approach]. Moscow, 488. [in Russian].

17. Lvovskiy E. (1988). Statisticheskie metodyi postroeniya empiricheskih formul: ucheb. posobie dlya vtuzov [Statistical methods for constructing empirical formulas: a tutorial for technical colleges]. Moscow. 239. [in Russian].

18. Dovidnik osnovnih pokaznikiv roboti regIonalnih filiy AT «Ukrayinska zaliznitsya» (2004-2019 roki). [Handbook of key performance indicators of regional branches of JSC "Ukrainian Railways" (2004-2019)]. Kyiv. 39. [in Ukrainian].

19. Pisarevskiy I.M., Balaka E.I., Balaka L.O. (2001). Osnovi ekonomIchnogo I sotsIalnogo prognozuvannya: navchalniy posIbnik [Fundamentals of economic and social forecasting: a textbook]. Kharkiv, 78. [in Ukrainian].

20. Tatsuno S. The technopolis strategy. NY: Brady Book-Prentice Hall Press, 1986. 344 p.

Yevgeniy Balaka ${ }^{1}, \mathrm{PhD}$ in Economics, Associate Professor of the Department of Transport Systems and Logistic, +38 057 730-19-55,

e-mail: ev.balaka@gmail.com.

Maryna Rezunenko ${ }^{1}$, PhD of Technical Sciences, Associate Professor of the Department of Higher Mathematics, +38 057-730-10-38

e-mail: rezunenko@kart.edu.ua

Volodymyr Vdovychenko ${ }^{2}$, doctor of Technical Sciences, Prof. Transport technologies Department, +38 050-403-17-10, e-mail: Vval2301@gmail.com

${ }^{1}$ Ukrainian State University of Railway Transport, 7, Feurbach sq., Kharkiv, 61050, Ukraine.

${ }^{2}$ Kharkov National Automobile and Highway University, 25, Yaroslava Mudrogo str., Kharkiv, 61002, Ukraine.

\footnotetext{
Порівняльний прогнозний аналіз пасажирських перевезень у дальньому залізничному та міжміському автобусному сполученнях Анотація. Проблема. У статті подано методичні підходи до визначення обсягів пасажирського обслуговування в дальньому залізничному та міжміському автобусному сполученнях територією Украӥни, які прогнозуються на наступні роки. Мета. Метою дослідження є збільшення рівня достовірності інформаційної бази для прийняття обтрунтованих управлінських рішень щзодо подальшого розвитку транспортного пасажирського комплексу. Методика. У процесі дослідження застосовувалась сукупність методів
} 
експертного та логічного аналізів можливих факторів впливу; економіко-математичне моделювання; формалізовані методи екстраполяиії для визначення прогнозних параметрів факторів впливу. Результати. Отримано прогнозні значення кількості перевезених пасажирів та величин пасажирообігу в дальньому залізничному та міжміському автобусному сполученнях за короткостроковий період. Орихінальність. Для визначення прогнозних величин обсягів пасажсирських перевезень застосовано сумісне використання методів кореляиійно-регресійного аналізу та прогнозування величини факторів методом змінної середньої. Практичне значення. Здійснене дослідження закономірностей динаміки обсягів пасажирських перевезень дозволило встановити, що протягом наступних двох років не очікується відчутних змін в обсягах роботи обох видів транспорту. Проте в дальньому залізничному сполученні можливе збільшення перевезення пасажирів на 1,6\% (0,74 млн.nac.), а отже, $і$ річний пасажирообіг зростатиме на 2,2\%. В автобусному міжміському сполученні можливе невелике зменшення обсягу пасажирських перевезень на 0,8\% (0,93 млн.nас.), а темпи зменшення річного пасажирообігу становитимуть 0,5 \%. В умовах постійного скорочення населення України най- ефективнішим механізмом забезпечення подальшого сталого розвитку ичих видів пасажсирських перевезень є постійне коригування тарифної політики на принщипах гнучкості та формування преміального тарифу за умови постійного підвищення якості послуг.

Ключові слова. прогнозування, пасажирські перевезення, залізничне сполучення, автобусне сполучення, кореляціийно-регресійний аналіз.

Балака Свгеній Іванович ${ }^{1}$, к.е.н, доц. каф. транспортних систем та логістики, +38 057 730-19-55, e-mail: ev.balaka@gmail.com. Резуненко Марина Євгенівна ${ }^{1}$, к.т.н, доц. каф. вищої математики, +38 057-730-10-38

e-mail: rezunenko@kart.edu.ua

Вдовиченко Володимир Олексійович ${ }^{2}$, д.т.н., проф. каф. транспортних технологій,

+38 050-403-17-10

e-mail: Vval2301@gmail.com

${ }^{1}$ Український державний університет залізничного транспорту, площа Фейєрбаха, 7, м. Харків, 61050, Україна.

${ }^{2}$ Харківський національний автомобільнодорожній університет, вул. Ярослава Мудрого, 25, м. Харків, 61002, Україна. 